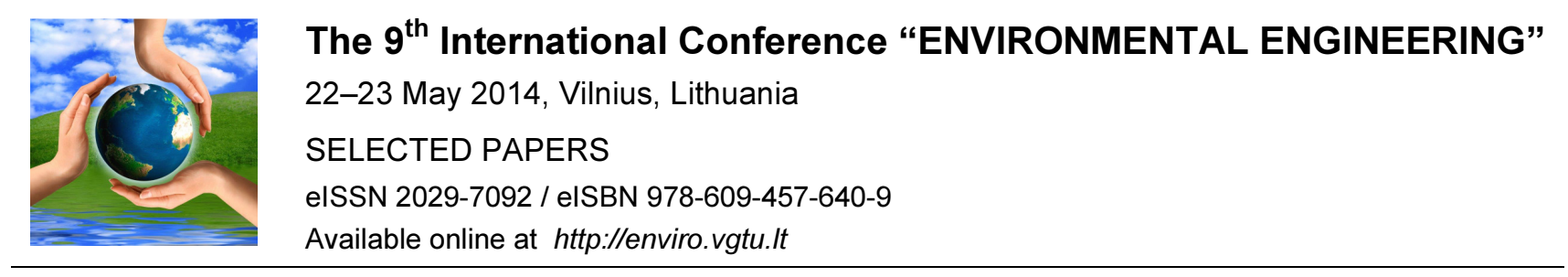

Section: Environmental protection

\title{
The ecological diversity of vegetation along the anthropogenic gradient in Silesia-Cracow Upland
}

\author{
Dorota Rożek \\ University of Silesia, Faculty of Earth Sciences, Bedzinska 60, Sosnowiec 41-200, Poland
}

\begin{abstract}
The research was conducted in the south-east part of Cracow-Czestochowa Upland, along the catena Niegowonice Rocks - Zamczysko Mountain which characterises by the great variety of relief and anthropogenic pressure. The catena passed through the areas built by calcareous, sandy and sandy-loamy deposits. That region characterises by the differential intensification of the anthropogenic pressure on the type of vegetation. Along the studied catena there were investigated some floristic composition analyses and the characteristic of habitats by means of the ecological indicator values, widely used in the research of plant ecology. Based on the ecological values, the following groups of plants were distinguished: saxifrages grasslands, xerothermic grasslands, beech forests, alder forests and artificial planted trees. The analyses have shown that the vegetation was completely various and changed by the human impact on the majority of the studied area. Moreover, the species of habitats typical for calcareous species were replaced by Pinus sylvestris, Quercus rubra and other, that have had a significant influence on the further functioning of these ecosystems. The human activity caused the impoverishment of flora and vegetation on the particular fragments of that region. The anthropogenic pressure led also to the modification of habitat demands of plants.
\end{abstract}

Keywords: vegetation diversity; catena analyses; anthropogenic impact; southern Poland.

\section{Introduction}

Vegetation cover is the element of the environment the most susceptible to all changes of the other components of a geosystem [1]. Soil consist a crucial factor in the formation of structure and species composition of plant communities. Vegetation cover and soils, both are dependent on topography and soil parent material [2] so it is important to investigate many components of landscape in the same time, taking also the interactions between them and the human impact into account. Moreover, some authors like Šimanauskiene \& Rahmonov [3] have presented the methods of geobiocomplex research.

The concept of "catena" was used for the first time by Milne [4] in the pedological research. He determined catena as a typical soil sequence which is located on the slope, homogenous in respect of climate and geology. Later also other authors have used it for soil investigations: Sommer and Schlichting [5] who classified the catenas, Akagi et al. [6], Clemens et al.[7], Gobin et al.[8], Gobin et al. [9] who identified catena with "toposequence" and use it in agriculture research.

A change in topography usually causes a differentiation of the water relationships. In the case where the groundwater level is near the day surface in topographic lows, changes in soil horizons in different places of the catena are particularly clearly pronounced [10]. The other authors expand on the concept of catena and use it in research of plant-soil cover [1, 1012].

Because the abiotic components of habitats are inseparably connected with the plant cover, catena could be defined as a sequence of biotops. It should be more precisely named "plant catena", like propose Rożek [13]. The term "sequence" is used to define the spatial sequence of soil types caused by the naturally determined changes of one of the soil-forming factors (geological basement and the changes in topography).

Krakow-Czestochowa Upland, located in the southern part of Poland, is a very differential region in terms of plant cover, soils, relief and geology. Moreover, it has been under intensive anthropogenic pressure since centuries, caused by agriculture, pasture, $\mathrm{Zn}-\mathrm{Pb}$ mining and metallurgy, urbanization.

Corresponding author: Dorota Rożek. E-mail address: dorota.rozek87@gmail.com

http://dx.doi.org/10.3846/enviro.2014.050

(C) 2014 The Author. Published by VGTU Press. This is an open-access article distributed under the terms of the Creative Commons Attribution License, which permits unrestricted use, distribution, and reproduction in any medium, provided the original author and source are credited. 
The aim of this study was the evaluation of differentiations in the habitat demands of plants of Smolen-Niegowonice Belt caused by the anthropogenic pressure by means of the ecological indicator values. This evaluation was executed by the comparison of indicated values between the key plots characterising by the similar habitat conditions and with respect to the map of potential vegetation.

\section{Study area}

The studied catena was traced in the western part of Smolen-Niegowonice Belt south of Ogrodzieniec (village in the southeast part of Cracow-Czestochowa Upland). It divide the analysed area (which has $13 \mathrm{~km}$ in length and $2 \mathrm{~km}$ in breadth) in the middle (Fig. 1). It characterise by the variety of environmental components: geological setting, relief, soil and plant cover, despite of the small size of terrain (Fig. 1). All hills are built by oxfordian limestone which cover the Triassic carbonate basement. Niegowonice Rocks (as a residual hills) are separated from the rest of Jurassic cuesta by Centuria river valley covered with the Holocene alluvial deposits. The rest of terrain is built by the Pleistocene fluvioglacial sands and gravels. Owing to the diversity of geologic structure, the different types of soil have developed there: podzols, rendzinas and hydrogenic soils. The plant communities which are supposed to develop on those soils are presented in Fig. 1C.

WSW

ENE

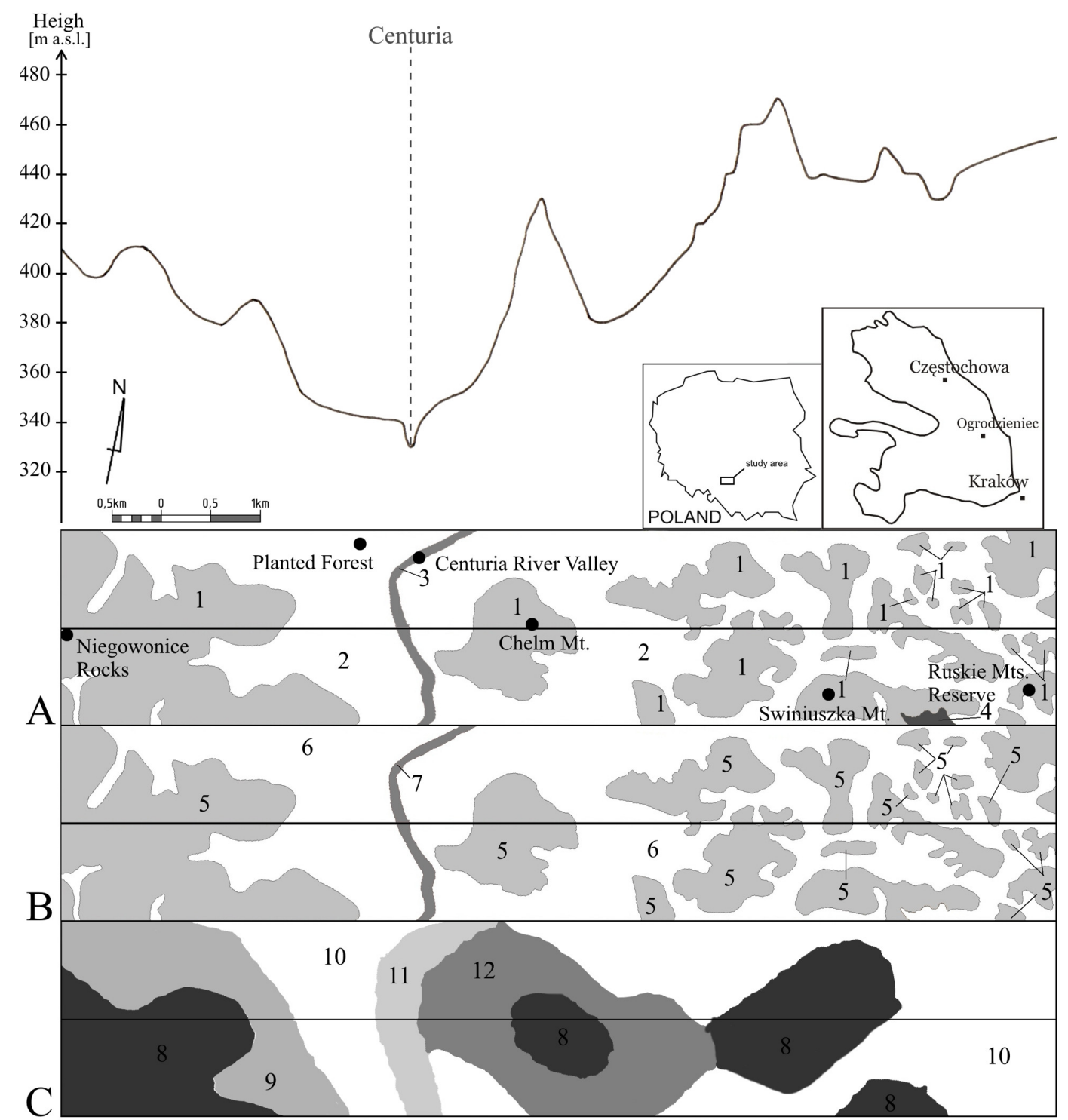

Fig. 1. Topographic profile, geology, soils and potential natural vegetation of study catena. A - geology: 1 - Jurassic limestone, 2 - Pleistocene fluvial and fluvioglacial sands and gravels, 3 - Holocene alluvial deposits, 4 - Pleistocene loes; B - soils: 5 - rendzinas, 6 - podzols, 7 - hydrogenic soils; $\mathbf{C}$ - potential natural vegetation: 8 - Dentario enneaphylidisFagetum (submontane forb-rich sudetian beech forest), 9 - Querco roboris-Pinetum, Serratulo-Pinetum (continental mesotrophic oak-pine mixed forest), 10 - Leucobryo-Pinetum, Cladonio-Pinetum, Molinio-Pinetum (Middle-European pine forest), 11 - Circaeo-Alnetum (lowland alder and ash-alder forest), 12 - Tilio Carpinetum (subcontinental colline lime-oakhornbeam forest). 


\section{Materials and methods}

The plant catena analysis let to present the relations between several components of the environment (e.g. soil and plant cover). It is a simple way to show the typical landscape of the part of Silesia-Cracow Upland with its diversity. It allows also to determine an anthropogenic influence in the plant cover. After literature and maps analysis, six key plots were determined to detailed research away: Niegowonice Rocks (I), planted pine forest (II), Centuria river valley (III), "Chelm Mountain" reserve (IV), Swiniuszka Mountain (V), "Ruskie Mountains" reserve (VI) (Fig. 1). They are characterized by the diversity of landscape components: geological structure, relief, soils and plant cover. Because of that diversity, the research consisted of detailed observation of habitats and determination of species within key plots, based on Nawara [14], SudnikWójcikowska \& Cwener [15] and Witkowska-Żuk [16]. For all 6 key plots it has been done the detailed list of plant species: 110 species were identified.

Among the key plots the following groups of plants were distinguished: saxifrages grasslands, xerothermic grasslands, beech forests, alder forests and artificial planted forests. It was obvious that those communities are far different from those which were suppose to be there (Fig. 1C).

It was important to find a useful method to evaluate how the habitat demands of present plants form and how very different they are within the key plots characterise by similar or equal landscape conditions. For this purpose, it has been determined some selected ecological indicator values of identified vascular plants after Zarzycki et al. [17]. There are several different values but four of them were the most useful in that research: climate values: light, temperature and edaphic values: trophy, soil granulometric.

Although the development of plant cover is dependent on many habitat components, the climate and type of substratum play a major role. Because there are so different types of plant communities within the study area and some of them are not completely natural, the temperature value may indicate how wide the ecological tolerance the indicated species have. Similarly, the analyses of light value let to indicate the differences between plant communities developed in the same substratum, but transformed by human activity. Moreover, if some species e.g. preferring more shady conditions have appeared within the grassland community it may indicate a progressive succession into the bush or forest community. Simultaneously, the soils and parent rocks constitute the specific alkaline conditions (rendzinas and limestone) or acidic conditions (podzols and sands, gravels), which only some kind of plants prefer. So, if there are some plants preferring more acidic conditions growing in the calcareous substratum, it is the evidence of unnatural changes, caused by human impact.

\section{Results}

The following figures 2-5 present the percentages of species from all six key plots which obtain the determined ecological indicator values (light, temperature, trophy, soil granulometric). Those values have 5-grade scales where the intensity of particular factors increases from 1 to 5. Some of species occupy conditions ranging the interval e.g. 3-4.

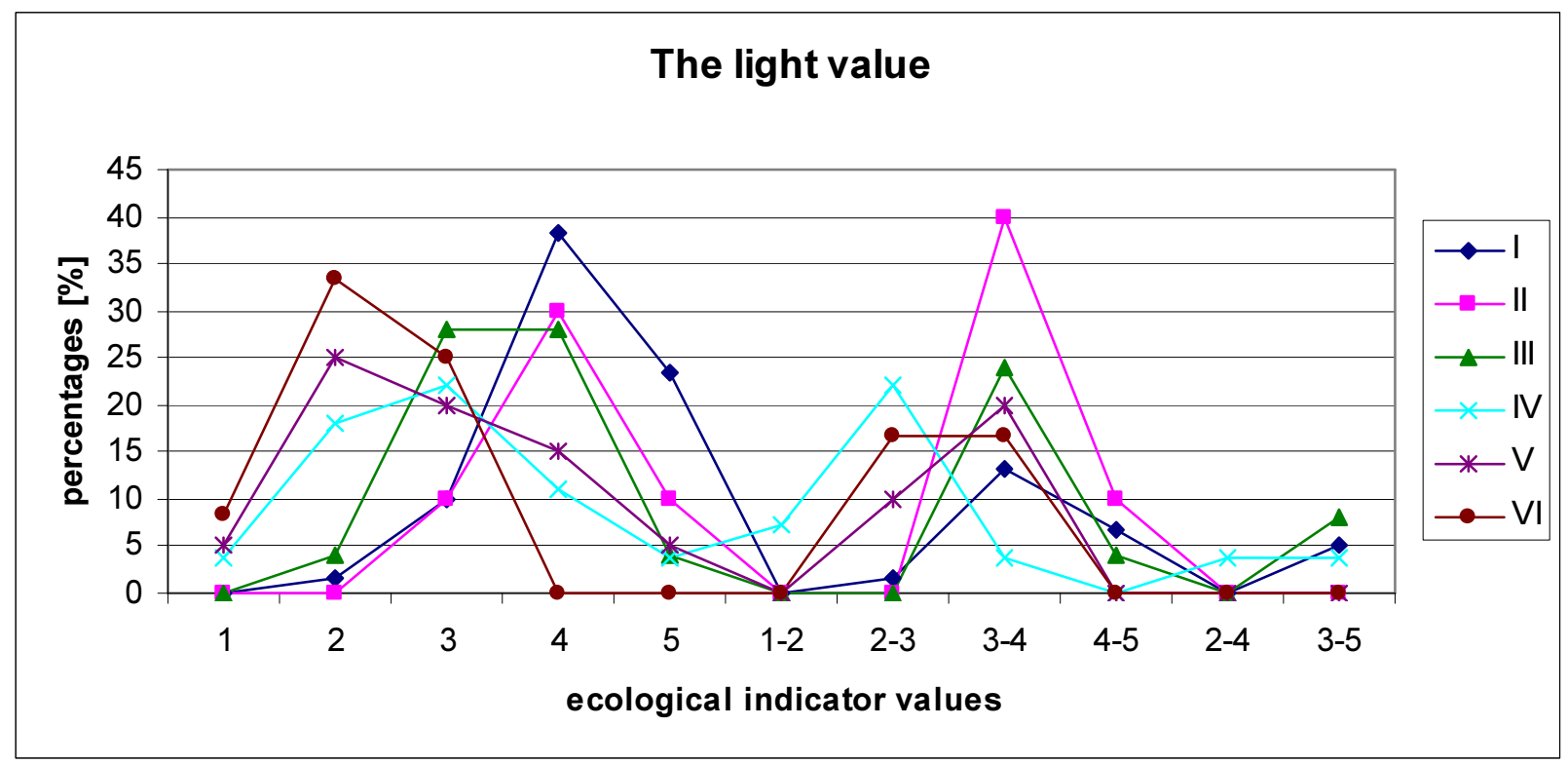

Fig. 2. The light value. $\mathbf{1}$ - deep shade, $\mathbf{2}$ - moderate shade, $\mathbf{3}$ - half-shade, $\mathbf{4}$ - moderate light, $\mathbf{5}$ - full light. 


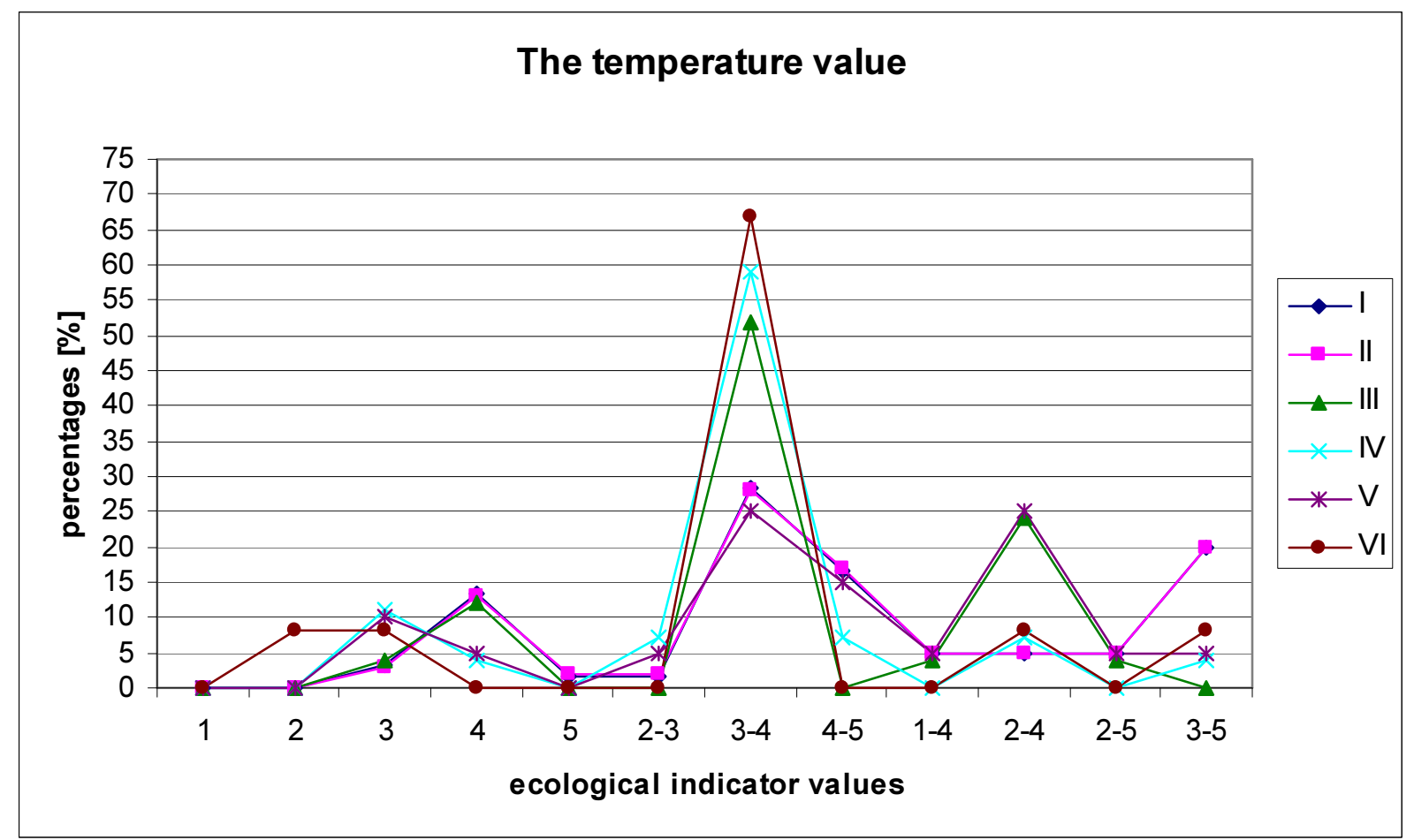

Fig. 3. The temperature value. $\mathbf{1}$ - coldest regions in the country, mainly alpine and subnival zones, $\mathbf{2}$ - moderately cold areas, mainly subalpine and upper mountain zones, $\mathbf{3}$ - moderately cool climatic conditions, $\mathbf{4}$ - moderately warm climatic conditions, $\mathbf{5}$ - warmest regions and microhabitats.

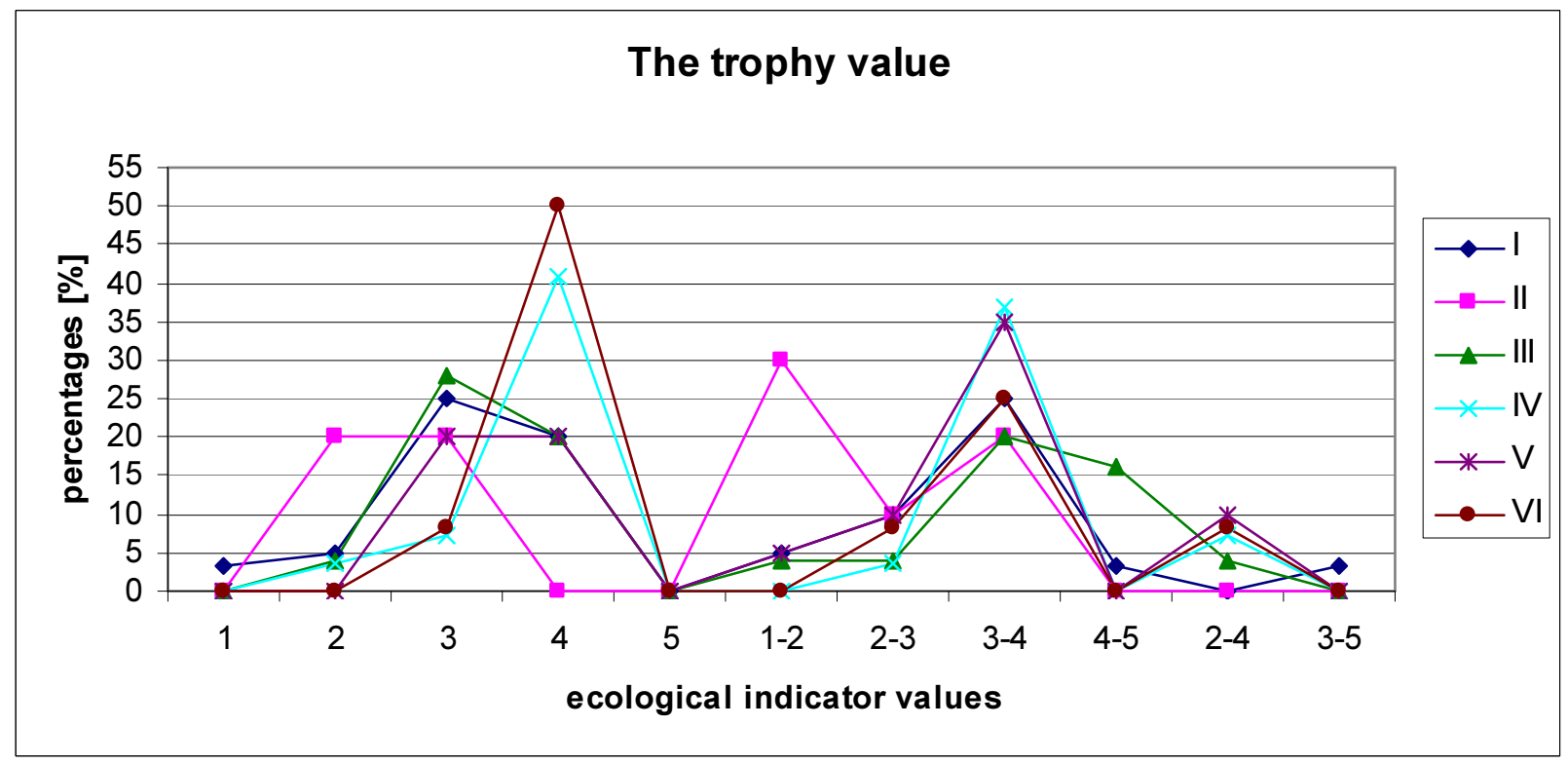

Fig. 4. The trophy value. $\mathbf{1}$ - soil extremely poor (extremely oligotrophic), $\mathbf{2}$ - soil poor (oligotrophic), $\mathbf{3}$ - soil moderately poor (mesothrophic), $\mathbf{4}$ - soil rich (euthrophic), $\mathbf{5}$ - soil very rich (extremely fertile). 


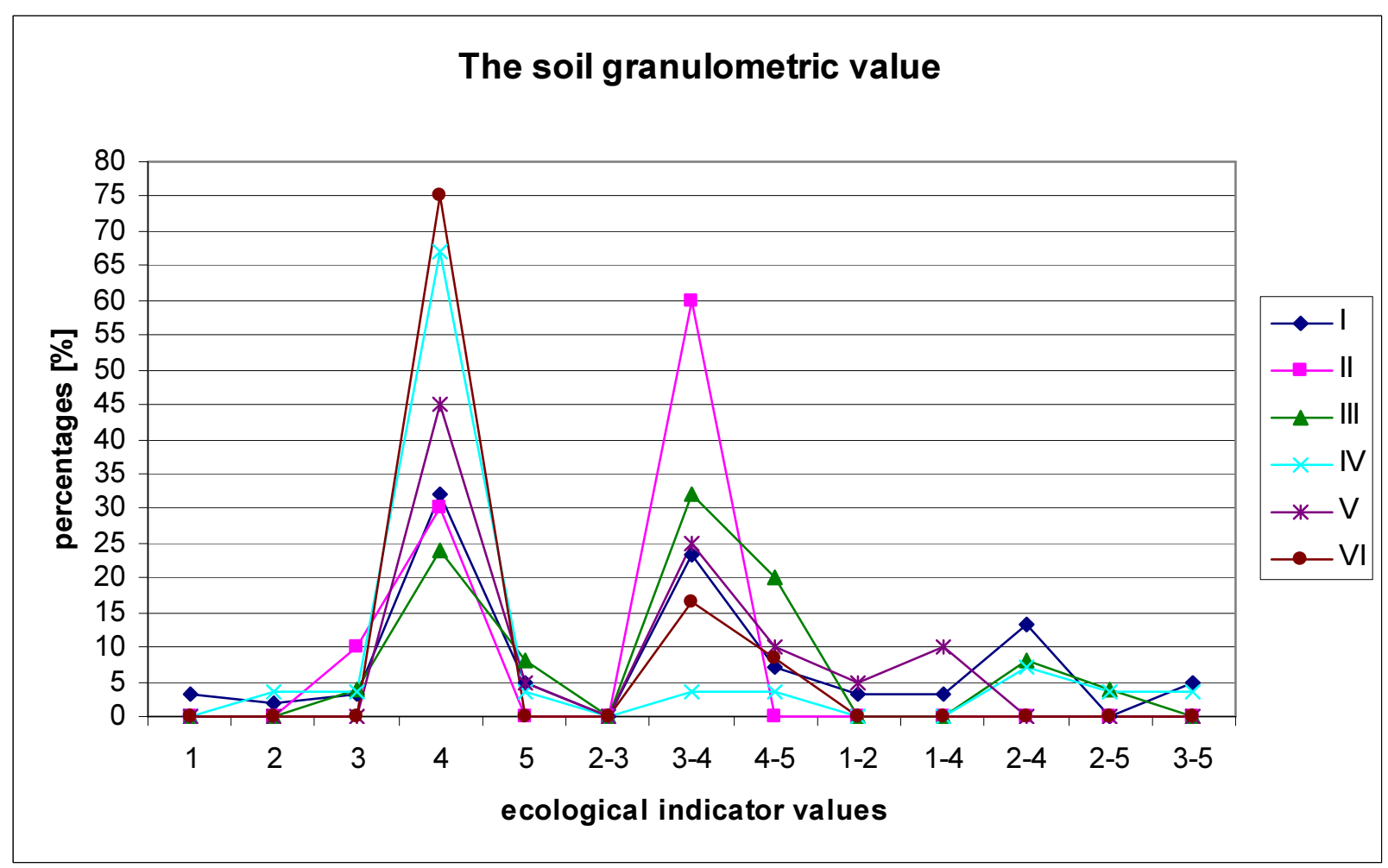

Fig. 5. The soil granulometric value. 1 - rocks and rock crevices, 2 - rock debris, scree, gravel, 3 - sand, 4 - argillaceous clay and dusty deposits, 5 - heavy clay and loam.

\section{Discussion and conclusion}

Silesia-Cracow Upland has been under the influence of human activity for centuries. It is an mostly agriculture region, bordering with the Upper-Silesian Industrial District. Within the Silesia-Cracow Upland the industry has also developed. The most common activity was the limestone burning in the special stoves (polish "wapienniki"), but the most transformed area constitute the Olkusz ore mining district with the $\mathrm{Zn}-\mathrm{Pb}$ mines and foundries. In the past that region was also used as a pasture area. Its forests have been cutting down and replaced by fields and pastures [18-19], then, they have constituted the source of wood for surrounded $\mathrm{Fe}, \mathrm{Pb}-\mathrm{Ag}, \mathrm{Zn}-\mathrm{Pb}$ ore mining foundries [20-21]. All those activities have had a great influence on the environmental components transformations, especially on biotic component like soil-alga crust (investigated inter alia by Cabała et al. [22]) and plant cover [10, 23-24].

The plant communities are an easily recognizable landscape component which is the most susceptible to change in other components and to the anthropogenic pressure. The soil-plant sequences and the relations between them are the most frequently analysed. In Poland some phytosociological-pedological research was done near Szczecin [25], in Tatras Mountains [26] and in Bieszczady [27]. Some research about the soil-vegetation interactions were done by e. g. Dębicki et al. [28], Walczak [29], Kobus [30] and Bednarek et al. [31]. The catena analysis was used inter alia in Wigry National Park [1] and in Rawska High Plain [32]. It has already been used in Krakow-Czestochowa Upland by Rahmonov et al. [10], Kobylecka [33] and Szczypek et al. [34]. All those analyses were strongly reliant on detailed soil research.

However, it is valuable to notice that it is possible to evaluate the plant cover differentiation and its changes caused by human activity on the strength of detailed observation of habitats, determination of species and analyses of their habitat demands. The comparison between the map of the potential vegetation and the attachment of identified species to syntaxonomic units, also given by Zarzycki et al. [17]. Moreover, using the ecological indicator values it is possible to determine the changes in habitat demands of plants.

Centuries ago the studied area was covered by forests. The human activity has been changing the environment little by little. The deforestation for the agriculture and pasture needs gave place to other new species which have created the plant communities new for that area. Niegowonice Rocks (I), as many others limestone exposures, are covered by saxifrages and xerothermic grasslands. Although they developed because of human activity, they are one of the most recognisable elements of the upland landscape. Those communities are very rich and constitute a valuable component of the local environment. The most popular herbaceous species are e.g.: Vincetoxicum hirundinaria, Allium montanum, Scabiosa ochroleuca, Peucedanum oreoselinum, Achillea millefolium, Thymus serpyllum, Sedum acre, Sedum maximum, Euphorbia cyparissias, Asplenium ruta-muraria, Asplenium trichomanes, Echium vulgare). The ecological indicator values of species from that key plot confirm that the majority of them prefer the conditions from moderate to full light and half-shade (Fig. 2), from moderately cool to moderately warm climatic conditions and the warmest regions (Fig. 3), euthrophic and mesothrophic soils (Fig. 4), sands, argillaceous clay and dusty deposits in the basement (Fig. 5). Unfortunately the cessation of pasture 
caused the consecutive overgrowing of those grasslands. There are more and more bushes (e.g. Sambucus nigra, Cerasus avium, Cornus sanguinea, Frangula alnus, Rosa canina, Prunus spinosa) and young trees (e.g. Betula pendula, Fagus sylvatica, Quercus rubra, Quercus robur, Acer pseudoplatanus) which are replacing the herbaceous plants. It is the evidence of secondary, natural landscape and flora transformations and of the slow succession of species typical for that region. It is really probable that the habitat demands of plants will change in the course of time, along with the vegetation transformation.

The influence of anthropogenic pressure on the vegetation is clearly noticeable in the planted pine forest (II) and Swiniuszka Mountain (V). The first one is the example of the impoverishment of species. The principal species stayed the same (Pinus sylvestris), but there are not many other species now. All of them prefer the conditions from half-shade to full light (Fig. 2) but there are also some percentages of species characterised by wide habitat demands in the extent of temperature, e.g. Calluna vulgaris, Deschampsia flexuosa. All species growing there have different trophy demands (Fig. 4) while they prefer only sand and argillaceous clay with dusty deposits in the basement (Fig. 5). They constitute the plant community far poorer that the fully developed pine forest and characterise by wider habitat demands. Simultaneously, the Swiniuszka Mountain consists the example of the replacing the natural vegetation by the species typical for the other habitat. It is the exposure of limestone, so it should be covered with beech forest like e.g. "Chelm Mt." reserve or "Ruskie Mts." reserve. Unfortunately, that terrain has been deforested and planted by Pinus sylvestris, Quercus rubra; sporadically there are also some Abies alba or Picea abies. Directly near the limestone exposure there are the patch of the beeches, where the trees are really thin (not more than several centimetres in perimeter). But there are not many other species belonging to Fagetalia sylvaticae order. The species growing there have different conditional tolerance. There are species which prefer every light conditions (Fig. 2), most of the prefer climatic conditions from cool to the warmest, but there are also some which have wider preferences (Fig. 3). The preferences in trophy conditions an soil granulometric are also differential (Fig. 4-5). All those indicator values show, that the species growing there are not create the one particular community. Moreover, in the understory there are following species: Carpinus betulus, Juniperus communis, Corylus avellana, Euonymus verrucosa, Daphne mezereum. That forest is well developed but on the habitat not typical for it. The irrational forest management (economic pine forests planted on limestone) led to a disturbance of natural processes between soils and vegetation. In the natural conditions, the soils are beneficial for the occurrence of their intrinsic plant communities with species characteristic for that type of substratum [35]. In that case, the rendzinas have been planted by not calcareous plants, so it has had to change the properties of that soil and, in the consequence, has had a significant influence on the further functioning of that ecosystem.

The species indicated along the Centuria river valley characterise by the most differentiation of habitat demands (Fig. 25). There are also many species with wide ecological tolerance, especially in the range of trophy (Fig. 4). That community is compound by trees, bushes and herbaceous plants. Some of them are closely related to the wet habitat, e.g. Ranunculus repens, Padus avium, Dactylis glomerata, Alnus glutinosa and constitute the fragments of natural ash-alder forest. The valley has relatively bold slopes, so its bottom is not wide - there are about 6-8 meters for ash-alder forest to develop. Moreover, the presence of numerous species with the wide ecological requirements (Cruciata gabra, Fragaria vesca, Juncus conglomeratus, Knautia arvensis, Mycelis muralis, Rubus ideaus, Tussilago farfara) is the reflection of the influence of human impact on the study area. Some of them are related to pine forest which surround the bottom of the valley.

The last part of catena consists the reserves of submontane forb-rich sudetian beech forest. "Chelm Mt." reserve (IV) was founded in 1957 (the eldest reserve in Cracow-Czestochowa Upland) in the area of 15,56 ha. The second reserve, "Ruskie Mts." (VI) was founded in 2000 in the area of 153,65 ha. Although both reserves preserve the same forest unit, there are some visible differences in ecological requirements of species creating them. Despite "Chelm Mt." reserve was founded earlier, there are species characterise by more differential habitat demands, especially in the range of light preferences (Fig. 2) while the species from "Ruskie Mts." prefers less differential conditions. In the first one key plot there are also some species with the wide ecological tolerance, which are not present in the second one. In the range of soil granulometric preferences there are e.g. Peucedanum oreoselinum, Lamium purpureum and in the range of light conditions there are e.g. Moehringia trinervia, Mycelis muralis. It could be caused by the neighbourhood: "Chelm Mt" is surrounded by fields and artificial planted pines while "Ruskie Mts" are the part of the bigger extent of forests, so the first one is more exposed to the influence of human activity.

In conclusion, there are some kinds of human activity influence on habitat demands of plants:

- $\quad$ There are many differences between the habitat demands of plants which grow in the similar habitat conditions (e.g. Niegowonice Rocks, Swiniuszka Mt. and reserves), because the plant communities have been deeply changed by the human activity. The differences exist even within the same forest unit (two reserves), but they are caused by the surrounding.

- The secondary, natural landscape and flora transformations and the slow succession of species typical for that region caused the differences between in ecological requirements of herbaceous plants, bushes and young trees.

- Swiniuszka Mt. is the example of the replacement of natural vegetation by the species which are typical for another habitats. Although they are not suitable there, they consist a real concurrence for the species which are adapted to grow on the calcareous substratum.

- The planted pine forest consist also the example of replacement of natural vegetation, but in this case, there were species compatible with the substratum. However, it consist the example of the impoverishment of species, because it is not the fully developed pine forest. 
On the other hand, there is a great difference between the diversity of flora creating the dry grasslands (as Niegowonice Rocks) and covering wooded limestone rocks (as Swiniuszka Mountain). The first one is far richer, but it is not natural, simultaneously. So, if Niegowonice Rocks and another similar areas overgrow (retransforming into beech forests), it will be lost the valuable biodiversity in Cracow-Czestochowa Upland. In the beginning of XXI century some naturalists from Silesia formulated and originate the programme of active conservation for remit the cultural landscape of that part of Cracow-Czestochowa Upland with bare rocks and xerothermic grassland (polish "Owca Plus"). That programme covering the Zborów Mountain reserve [19,36] consists in monitored pasture of goats and sheep, next to cutting trees. The animals eating sprouts do not let them grow and develop, simultaneously they loosen soil preparing it for herbaceous plants. Owing to those interventions, the half-natural grasslands were remitted.

The Smolen-Niegowonice Belt is the part of south-east Crakow-Czestochowa Upland, so determined catena is the example of landscape typical for that region. It is greatly possible that the similar direction of vegetation transformation have happened in the areas adjacent to that belt, so it is very important to understand the mechanisms of changes in that region. The long-term human activity transformed it so far, that its results cannot be omitted in plans of the conservation and in evaluation of biodiversity of that region.

\section{References}

[1] Solon, J.; Degórski, M.; Roo-Zielińska, E. 2007. Vegetation response to a topographical-soil gradient, Catena 71: 309-320. http://dx.doi.org/10.1016/j.catena.2007.01.006

[2] Rahmonov, O. 2007. Relacje pomiędzy roślinnościa a gleba w inicjalnej fazie sukcesji na obszarach piaszczystych. Katowice: Wydawnictwo Uniwersytetu Śląskiego.

[3] Šimanauskienè, R.; Rahmonov, O. 2005. The problem of geobiocomplex distinguishing methodology, in The 6th International Conference "Environmental Engineering”, Selected papers, II: 999-1004.

[4] Milne, G. 1935. Some suggested units of classification and mapping, particularly for East African soils, Soil Research 4: $183-198$.

[5] Sommer, M.; Schlichting, E. 1997. Archetypes of catenas in respect to matter - a concept for structuring and grouping catenas, Geoderma 76: 1-33. http://dx.doi.org/10.1016/S0016-7061(96)00095-X

[6] Akagi, J.; Zsolnay, A.; Bastyda F. 2007. Quantity and spectroscopic properties of soil dissolved organic matter (DOM) as a function of soil sample treatments: Air-drying and pre-incubation, Chemosphere 69: 1040-1046. http://dx.doi.org/10.1016/j.chemosphere.2007.04.036

[7] Clemens, G.; Fiedler, S.; Dinh Cong, N.; Van Dung, N.; Schuler, U.; Stahr, K. 2010. Soil fertility affected by land use history, relief position, and parent material under a tropical climate in NW-Vietnam, Catena 81: 87-96. http://dx.doi.org/10.1016/j.catena.2010.01.006

[8] Gobin, A.; Camping, P.; Deckert, J.; Feyen, J. 1998. Integrated Toposequence Analysis at the confluence zone of River Ebonyi headwater catchment (south eastern Nigeria), Catena 32 173-192. http://dx.doi.org/10.1016/S0341-8162(98)00052-6

[9] Gobin, A.; Camping, P.; Deckert, J.; Feyen J. 2000. Integrated Toposequence Analyses to combine local and scientific knowledge systems, Geoderma 97: 103-123. http://dx.doi.org/10.1016/S0016-7061(00)00029-X

[10] Rahmonov, O.; Snytko, V.A.; Szczypek, T. 2010. Anthropogenic changes in landscape of the Krakow-Czestochowa Upland (Southern Poland), Geography and Natural Resources 31: 177-182. http://dx.doi.org/10.1016/j.gnr.2010.06.014

[11] Platonova, E.A. 2005. Analysis of Catenae in the Kivach Reserva: Structure, Succession State and Potentional Composition of Forest Vegetation, Russian Journal of Ecology 36(4): 252-258. http://dx.doi.org/10.1007/s11184-005-0065-3

[12] Rahmonov, O.; Rahmonova, M.; Snytko, V. A.; Szczypek, T. 2011. Anthropogenic disturbance to vegetation on the polygon-transect in the Kulikalon depression (Tajikistan), Geography and Natural Resources 32(4): 386-393. http://dx.doi.org/10.1134/S1875372811040147

[13] Rożek, D. 2013. The Catena Analysis in Determination of Vegetation Transformation under the Influence of Human Impact. Advanced Research in Engineering Science "ARES” 1(1), 9-15. Available from Internet: http://aresjournal.org/index.php?id=15. E-ISSN: 2347- 4130.

[14] Nawara, Z. 2006. Rośliny łakowe. Warszawa: MULTICO Oficyna Wydawnicza.

[15] Sudnik-Wójcikowska, B.; Cwener, A. 2012. Rośliny kserotermiczne. Warszawa: MULTICO Oficyna Wydawnicza.

[16] Witkowska-Żuk, L. 2008. Atlas roślinności lasów. Warszawa: MULTICO Oficyna Wydawnicza.

[17] Zarzycki, K.; Trzcinska-Tacik, H.; Różański, W.; Szelag, Z.; Wołek, J.; Korzeniak, U. 2002. Ecological indicator values of vascular plants of Poland. Krakow: W. Szafer Institute of Botany, Polish Academy of Sciences.

[18] Czylok, A.; Niewdany, J.; Tyc, A. 2006. Kraina Białej Przemszy, Przyroda i Człowiek. Olkusz: Stowarzyszenie Szansa Białej Przemszy.

[19] Czylok, A.; Ślusarczyk, M.; Tyc, A.; Urbanowski, M.; Waga, J.M. 2008. Przyrodnicze i kulturowe uwarunkowania zrównoważonego rozwoju obszaru Jury na przykładzie Podlesic. Zawiercie: Towarzystwo Miłośników Ziemi Zawierciańskiej i Wydział Nauk o Ziemi Uniwersytetu Śląskiego.

[20] Cabała, J. 2009. Metale ciężkie w środowisku glebowym olkuskiego rejonu eksploatacji rud Zn-Pb. Katowice: Wydawnictwo Uniwersytetu Śląskiego, $20-25$.

[21] Molenda, D. 1963. Studia z dziejów górnictwa i hutnictwa, Tom VIII, Górnictwo kruszcowe na terenie złóż śląsk-krakowskich do połowy XVI wieku. Wrocław-Warszawa-Kraków: Zakład Narodowy im. Ossolińskich, Wydawnictwo Polskiej Akademii Nauk

[22] Cabała, J.; Rahmonov, O.; Jablonska, M.; Teper, E. 2011. Soil algal colonization and its ecological role in an environment polluted by past Zn-Pb mining and smelting activity, Water, Air, \& Soil Pollution 215(1-4): 339-348. http://dx.doi.org/10.1007/s11270-010-0482-1

[23] Rahmonov, O.; Oleś, W. 2010. Vegetation succession over an area of a medieval ecological disaster. The case of the Błędów Desert, Poland, Erdkunde 64(3): 241-255. http://dx.doi.org/10.3112/erdkunde.2010.03.03

[24] Rahmonov, O.; Parusel, T. 2011. Vegetation succession and soil development in an area transformed by human impact - reclaimed ash landfills, in The 8th International Conference Environmental Engineering 1: 323-330.

[25] Celiński, F. 1962. Zespoły leśne Puszczy Bukowej pod Szczecinem, Monografie Botaniczne 13.

[26] Adamczyk, B. 1962. Studia gleboznawczo-fitosocjologiczne w Dolinie Małej Łaki w Tatrach, Acta Agr. et Silv. Ser. Silvestris 2, 45-116.

[27] Michalik, S.; Skiba, S. 1995. Ocena relacji między pokrywą glebową a roślinnością w Bieszczadzkim Parku Narodowym, Roczniki Bieszczadzkie 4, 85-95.

[28] Dębicki, R.; Skłodowski, P. 1999. The role of soil in functioning of ecosystems, Roczniki Gleboznawcze, 50(3) 5-20.

[29] Walczak, R.T. 1999. Modelling of processes in soil-plant-atmosphere-machine system, Roczniki Gleboznawcze, 50 : 3.

[30] Kobus, J. 1999. Interaction between soil, plant and microorganisms, Roczniki Gleboznawcze 50(3): 89-110.

[31] Bednarek, R. 2002. Diagenetic changes in sandy buried soils, Paleopedology problems in Poland. Łódź: Łódzkie Towarzstwo Naukowe, 47-57. 
[32] Degórski, M. 1990. Warunki siedliskowe kateny ekosystemów leśnych na Wysoczyźnie Rawskiej (ze szczególnym uwzględnieniem dynamiki wodnotroficznych właściwości gleb), Dokumentacja Geograficzna, Zeszyt 5-6.

[33] Kobylecka, S. 1981. Stosunki litologiczno-glebowe Wyżyny Żarkowsko-Częstochowskiej. Katowice: Wydawnictwo Uniwersytetu Śląskiego, 85.

[34] Szczypek, T.; Wika, S. 1978. Wpływ rzeźby terenu na charakter zbiorowisk roślinnych na obszarze wydmowym w okolicy Piłki (północna część Wyżyny Śląskiej), Geographia, Studia et Dissertationes 2.

[35] Matuszkiewicz, W. 2008. Przewodnik do oznaczania zbiorowisk roślinnych Polski. Warszawa: PWN, $341-346$.

[36] Czylok, A.; Ślusarczyk, M.; Tyc, A.; Waga, J.M. 2010. Wypas zwierząt gospodarskich jako sposób czynnej ochrony krajobrazu i różnorodności biologicznej rezerwatu przyrody Góra Zborów, Prądnik. Prace Muz. Szafera 20: 175-184. 